\title{
Educating the Precariat: Intern Labour and a Renewed Approach to Media Literacy Education
}

\author{
Doug Tewksbury \\ Niagara University, Lewiston, USA, dtewksbury@niagara.edu
}

\begin{abstract}
As internships have become more common in the production of media content, the media literacy movement has been neglectful in addressing the role of labour in general and internship labour in particular as a necessary component in deconstructing media content. This paper argues that media literacy educators should teach citizens to understand not just the content and grammar of media production, but also the labour conditions that underlie the creation of this content, with internships being among the most exploitative development in recent years and representative of a larger issue of worker precarity. The paper concludes with a call for reforms to media literacy pedagogy to address workers' rights and dignity in media and creative industries.
\end{abstract}

Keywords: internships, media literacy, media education, precarity, labour, education, cultural studies, inequality

Acknowledgements: The author thanks the editors of this special issue for their comments, along with Dr. Christine Quail for her assistance in discussing and developing the themes of this article. I am especially grateful to my students who volunteered to share their internship experiences with me for use in this article.

From January through August of 2011, Diana Wang was an unpaid intern at Harper's Bazaar, a Hearst-owned magazine, in New York City. She was 28; it was her seventh internship. She served as "head intern" in the magazine's accessories department, supervising eight other interns while shuttling bags across New York City and overnighting hats to London, for 40 to 55 hours per week. She received no pay for this work (Adams, 2013). Similarly, in 2009-2010, Eric Glatt was a 41-year old unpaid intern, one of 20 on the Fox Searchlight film Black Swan. Hoping the experience would translate into a film editing position, Glatt instead was a personal assistant to the film's executive staff, sent on errands to purchase scented candles and hypoallergenic pillows (Miller and Horn 2014). Both Wang and Glatt successfully sued in lawsuits that were noticed in both the popular and business press, but they were not alone: from June to August 2013, lawsuits were filed by current or former interns against Condé Nast Publications, Warner Music Group, Atlantic Recording, Gawker Media, Fox Entertainment Group, NBC Universal, Viacom, Sony, Universal Music Group, Bad Boy Entertainment, Donna Karan, and Charlie Rose, Inc. (Becker 2013; Jacobs 2013; Greenhouse, 2013; Perlin 2013a; Spitznagel 2013). As Glatt stated of the Black Swan case, "It was nauseating to see how easily employers could get free labor just by slapping the title 'internship' on something" (Perlin 2013b).

To date, media studies and communication scholarship has generally moved slowly on the issue of labour until its recent turn toward the subject (Fuchs and Sevignani 2013). The field's shift in attention toward labour is important, not only because exploitative material and immaterial labour practices are tightly woven into the business model of many Web 2.0 participatory platforms, but also due to the increasingly precarious status of media workers in these positions (Berlant 2011; Standing 2011).

The time has come for labour to be, as Vincent Mosco states, "placed high on the agenda of projects for the renewal of cultural studies" $(2011,230)$. Capital's unchecked drive to secure cheap labour is a central force leading to exploitative working conditions-human slavery being perhaps the most extreme example-but has also resulted in the rise of hegemonic cultural and political mechanisms that reinforce class divisions. Capitalist production has always had labour at the center of its attention, and inherent in the logic of this production is 
the drive to reduce labour costs in a race to the bottom to increase profits for investors and owners. Today that logic has resulted in the spread of internships, an increasingly troubling development in modern labour practices and in media industries in particular.

The need for renewed critical scholarship on this issue among researchers is clear. It is also necessary that educators develop a pedagogy of media education that includes addressing the labour conditions involved in the production of media. I argue that the media literacy movement must begin to take seriously not only media production labour considerations in general, but the role of internships in particular, as a fundamental part of a holistic, critical media education.

Neither issue has been particularly well addressed in media literacy education. James W. Potter (2004), for example, provides 41 definitions of media literacy from a variety of scholars, educators, or organizations, yet not a single one mentions the subject of work or labour $(24-28,257-260)$. As interns are increasingly being asked to function as de-facto replacements for paid employees as a cost-saving measure to return value to shareholders or owners (Becker 2013; Harrison 2012; Miller and Horn 2014), they currently fall into a precarious space where they neither enjoy the compensation nor possess the rights of employees (Perlin 2011).

Laws and policies protecting both paid employees and unpaid interns from exploitation are already on the books in the United States through the Fair Labor Standards Act, in Canada through a number of provincial regulations, and through similar policies in many developed nations, but are generally unenforced (United States Department of Labor 2010; Ontario Ministry of Labour 2000; British Columbia Ministry of Labour 1996). Many unpaid internships could be read as a violation of the assertion in the United Nations' Universal Declaration of Human Rights that "Everyone has the right to work, to free choice of employment, to just and favourable conditions of work and to protection against unemployment... [and] without any discrimination, has the right to equal pay for equal work" (1948, Article 23).

If the media literacy movement is designed to teach media audiences the skills to identify and resist hegemonic structures in terms of media content, then it is equally important that it teach citizens and future media workers to identify and resist hegemonic structures inherent in the labour processes that produce that media. That is, for our students to be more fully media literate, media educators must teach them to understand not just the content and grammar of production, but also the material labour conditions that underlie the creation of content in media industries.

\section{Educating a Media Literate Public}

Media literacy is a broadly based, democratically rooted, interdisciplinary approach of citizen media education and empowerment (Kellner and Share 2005; Lewis and Jhally 1998; Potter 2004, 2013). A fundamentally critical endeavor that "must be conceived as a political, social, and cultural practice" (Sholle and Denski 1994, 17), the roots of media literacy lie in critical literary studies-based arguments, namely that it is necessary to cultivate citizens who have the capacity to use socially constructed forms of communication and media representation, particularly through deconstructing media discourses, and through both classroom curricula and popular discursive campaigns. Importantly, media literacy also provides a productionbased method of teaching citizens the skills necessary to make their own media (Macedo 2006).

Among its strengths, the media literacy agenda has a tradition of focusing its attention on media content itself, casting a critical eye toward issues of representation and identity, as well as political economic arguments about media ownership and consolidation as reinforcing mechanisms for hegemonic media content. It is important to remember that the media literacy movement is a political project. It encourages individuals to consume media critically and create content that works toward creating more democratic media structures, and aims to contribute more voices to the public sphere, particularly those that cross disciplinary boundary lines or challenge structures that reinforce hegemonic or ideological systems. 


\section{Internships and Media Literacy Education}

A weakness, however, is that media literacy education has not been especially adept at addressing the issue of labour conditions in the production of media content. And in the creation of media content, among the most exploitative labour practices in recent years has been the unpaid internship. Internships-both paid and unpaid-have become such a common practice in the media and creative industries that there has been an explosion in the number of such positions in firms both large and small, as intern labour has become a de-facto replacement for the paid worker, if not a prerequisite for those who wish to eventually work in these fields (Kuehn and Corrigan 2013; Perlin 2011).

The unpaid internship has become an increasingly prominent topic in both scholarly and popular consciousness, most notably through Ross Perlin's Intern Nation: How to Earn Nothing and Learn Little in the Brave New Economy (2011). Media industries have been called out for being among the worst offenders in exploiting unpaid labour. The consolidation of media industries, the high salaries at the top of the star system, the gutting of union protections, and the ever-present pressure to provide strong quarterly returns to investors has led media producers in a race to the bottom to control costs (Mansell 2004; McChesney 2008, 2013; Mosco 2011). Labour is usually among the most important financial costs to companies in large-scale productions, but this is also true in smaller fields, such as advertising, web programming, music recording, and book publishing.

And the numbers are troubling. Perlin (2011) notes that no exact figures are kept by the U.S. Department of Labor or Bureau of Labor Statistics, but it is estimated that there are between one and two million interns in the United States as of 2013. Canada does not keep statistics on internships, but Toronto labour lawyer and activist Andrew Langille estimates the number of interns to be between 100,000 and 300,000 (Sagan 2013). Kate Harrison (2012) claims that approximately two-thirds of North American internships are unpaid, most often those taken for college credit. Media industries in particular tend to offer the unpaid internship as an entry point for future media careers (Cumming 2014; Harrison 2012; Olson 2013). However, what has come to light through the recent spate of lawsuits is that the business models in these industries are in effect reliant on the unpaid labour of interns to offset the cost of production assistants, studio assistants, journalists, game testers, and personal assistants (Becker 2013; Jacobs 2013; Perlin 2013a; Spitznagel 2013). In addition to the often unpaid and vulnerable nature of these positions, media firms have the added advantage of no costs associated with healthcare, other benefits, or overtime, let alone worrying about the workplace protections that are available to full-time employees. If interns complain, companies can send them home. As Matthew Saccaro (2014) notes,

Employers already pay interns a low wage for the amount of work they do. One manager derisively referred to an intern as a "22-22-22," as in a 22-year-old who's willing to work 22-hour days for $\$ 22,000$ a year. With waves of high school students entering the internship market, why hire a 22-22-22 when you can hire a 16-year-old and pay them in exposure, experience and exhaustion?

Despite the recent lawsuits filed against a number of media conglomerates, the cultural acceptance of internships has proven to be difficult to overturn. Media industries were decades ahead of others in building the internship model into the prerequisite for employment, and as such, the reliance on unpaid labour is central to the business model of many commercial media. Christopher Knab (2008), for example, echoes commonplace advice for interns in the recording industry:

Nothing is more impressive than having done some work as an intern. Businesses that offer internships may demand a lot of you. They may (and will) test your patience by having you do what you think are mundane, boring, or menial tasks [...] Stick it out. Most likely you are being given a form of initiation. Most people in the recording industry started out doing menial tasks and when given the chance to express their skills [...] did so, and were rewarded with jobs, job-leads, promotions or recognition of some kind. 
While anecdotal, there are many similar stories reported from my own Media Studies advisees placed in for-credit internship positions in recent semesters. One student spent her unpaid internship semester grocery shopping for bands' tour riders every week, including being ordered to pick up a cake for her office from across town. Another student's video production internship involved one task, which was the single-take, hours-long filming of hockey practices every week. A third spent ten weeks doing nothing but logging tape for one of the largest network news affiliates in the nation. As a condition of her unpaid internship, another was required to sign a one-year non-compete agreement that did not allow her to work for another company in the same industry within a 60-mile radius for one year. My student advisees regularly take out loans to take advantage of their summer internships, particularly those in television news. One took out a $\$ 5,000$ loan to live in New York City for her internship, which paid her $\$ 16$ per day for ten weeks.

In each of these cases, although advised of their rights, students did not want to file a complaint with the university's co-op office about illegal or abusive internships, either out of fear that they would not get a letter of recommendation, the loss of class credit (and the financial burden associated with that), or the stigma of being labeled as a troublemaker. In a piece entitled "4 Coping Tips for Surviving a Crummy Internship," Lindsay Olson (2013) recommends toughing out the bad working conditions and "Comfort[ing] yourself with the fact that it'll look good on your résumé," because "It may not be clear to you how pouring coffee prepares you for a career in marketing, but your boss may be testing you to see how committed you are to learning the ropes."

Indeed, the usual subtext to most advice on internships is rooted in the discourse of "paying one's dues" and "sticking it out," ignoring rights violations, tolerating illegal activity, or living with harassment. The line on the resume or the letter of recommendation both function as reinforcements for hegemonic structures, keeping the workers in line through the fear of a bad review. Yet each of these threadbare arguments disregards identity- or class-based discrimination, whether structural or overt, in place of an idealized meritocracy where individual hard work and perseverance is the formula for a prosperous future. It is difficult, to be sure, as the role of media literacy educators isn't to encourage students to forego the career options that would put them in the very positions where they will be able to make ethical decisions in the production of media content. However, this can only occur by cracking open the critical question of how media educators can build a coordinated, interdisciplinary curricular effort to teach those students interested in entering the creative industries to not only identify exploitative working conditions, but to organize to work against these practices through educational, political, and personal efforts.

\section{A Renewed Approach to Media Literacy Education}

The next step for media literacy education is to continue its development of a rights-based pedagogy that highlights conditions of social class and dignity in labour through advocating for workplace protections as part of a regime of worker and human rights. The democratic promise of a healthy public sphere requires equality of opportunity and leveling of unequal structures, an ethics that demands a worker environment that benefits workers, not capitalists, in the labour practices of media-making.

To implement these shifts, the media literacy movement must put into practice several common-sense reforms to incorporate labour considerations into its tradition of critical pedagogy. Awareness raising, particularly in terms of empowering students to push for the enforcement of law and policy, is a first step. One of the great success stories of the media literacy movement thus far is the way that it has drawn on critical intellectual traditions to normalize the discussion of themes such as media representations of beauty and body image, race and gender performativity, or sexuality and sexual orientation, all of which are topics raised by resistant narratives through oppositional readings of dominant discourses.

But providing an oppositional reading of labour considerations is not enough: media educators need to empower their students, intern and non-intern alike, to exercise their rights as 
cultural workers, and to work together toward principles of equitable worker treatment. Students who plan on a future career in media work need to start early to develop an identity that places an emphasis on themselves as workers, professional labourers with rights, skills, and experience, and as valuable beyond simply their ability to provide cheap freelance labour or free content in exchange for an abstract promise of experience in an internship. Yet these principles can be difficult for many students to grasp, given that the predominant tendency of the Web 2.0-era business model is to offload the labour of media-making onto users, usually for no pay, and digital-native students have spent their adolescence with the political conjuncture of free content and free labour as their reference point for how media industries work.

To convince them otherwise is a critical, normative pedagogical project, one that must provide an oppositional reading of labour considerations that translates awareness raising into action. Hearing from current media and cultural workers can be beneficial for future workers (provided those speakers don't reinforce the "pay your dues" narrative that has long dominated much of the career advice given to students). Getting university internship and coop offices to protect the interns that they are sending out into the field can also be difficult, particularly as these offices often rely on metrics regarding placements instead of the quality of the internship or legality of the intern's position in the workplace. A general involvement with activism and direct democratic action can only help, as well, particularly as the goal of all of these efforts is enabling students to understand that social change is possible, and that the first step is empathy for and solidarity with the less powerful.

Similarly, collective worker action within and unionization of media workplaces are especially useful as protective measures-several of my own interns have not been allowed to touch a camera or editing equipment during their internships due to union rules-and educating students about their rights as workers is paramount. Furthermore, the incorporation of unions, collectives, or organizations into educators' curricula can show future media workers that the benefit of a intern and future worker education can actually provide relevant job training when done for the student's benefit but only when also focused on this practice within a framework of human and worker rights and dignity.

The Canadian Intern Association (2014), for example, is an advocacy group that unites interns for organized protection, comments on the legality of intern positions under Canadian provincial labour laws, and offers workshops and seminars to student groups. Lawsuits, both class action and individual, have already helped to pressure employers to realize that unpaid internships might not be as cheap as they think they are, as was the case in the recent Condé Nast and Charlie Rose, Inc. lawsuits led by unpaid former interns (Miller and Horn 2014; Perlin 2013a; Spitznagel 2013).

The labour conditions that underlie the creation of commercial media content directly affect the production of that content. But when those precarious conditions have become the norm for an exploitative system that enables the endless pursuit of profit and reinforces hegemonic structures of inequality, the problem becomes not one of future career preparation but one of ethics.

\section{References}

Adams, Susan. 2013. Is The Unpaid Internship Dead? Forbes, June 14. Accessed June 12, 2015. http://www.forbes.com/sites/susanadams/2013/06/14/is-the-unpaid-internship-dead/.

Becker, Amanda. 2013. PBS' Charlie Rose Settles with Unpaid Interns as Lawsuits Spread. Reuters, July 1. Accessed June 12, 2015. http://www.reuters.com/article/2013/07/01/entertainment-usinterns-lawsuit-charlie-idUSBRE9601E820130701.

Berlant, Lauren. 2011. Cruel Optimism. Durham: Duke University Press.

British Columbia Ministry of Labour. 1996. Employment Standards Act. Victoria, British Columbia. Accessed June 24, 2015.

http://www.bclaws.ca/EPLibraries/bclaws new/document/ID/freeside/00 9611301.

Canadian Intern Association. 2014. About Us. Accessed June 24, 2015. http://www.internassociation.ca/about/. 
Cumming, Ed. 2014. Interns Should Stop Complaining and Do a Proper Day's Work. The Telegraph, September 30. Accessed June 12, 2015. http://www.telegraph.co.uk/men/thinkingman/10340044/Interns-should-stop-complaining-and-do-a-proper-days-work.html.

Fuchs, Christian and Sebastian Sevignani. 2013. What Is Digital Labour? What Is Digital Work? What's Their Difference? And Why Do These Questions Matter for Understanding Social Media? tripleC: Communication, Capitalism \& Critique. Open Access Journal for a Global Sustainable Information Society 11 (2): 237-93.

Greenhouse, Steven. 2013. Judge Rules for Interns Who Sued Fox Searchlight. The New York Times, June 11, sec. Business Day. Accessed June 24, 2015.

http://www.nytimes.com/2013/06/12/business/judge-rules-for-interns-who-sued-foxsearchlight.html.

Harrison, Kate. 2012. Why Interns Are Your New Best Friends. Forbes, November 7. Accessed June 24, 2015. http://www.forbes.com/sites/kateharrison/2012/07/11/why-interns-are-your-new-bestfriends/.

Jacobs, Deborah. 2013. Unpaid Intern Lawsuits May Reduce Job Opportunities. Forbes, September 24. Accessed July 11, 2015. http://www.forbes.com/sites/deborahljacobs/2013/09/24/unpaid-internlawsuits-may-reduce-job-opportunities/.

Kellner, Douglas, and Jeff Share. 2005. Toward Critical Media Literacy: Core Concepts, Debates, Organizations, and Policy. Discourse: Studies in the Cultural Politics of Education 26 (3): 369-86.

Knab, Christopher. 2008 July. Do's and Don't for Audio and Other Music Oriented Interns: Or, How to Impress Your Internship Employer and Become Successful in the Recording Industry. Music Biz Academy. Accessed June 24, 2015. http://www.musicbizacademy.com/knab/articles/interns.htm.

Kuehn, Kathleen and Thomas F. Corrigan. 2013. Hope Labor: The Role of Employment Prospects in Online Social Production. The Political Economy of the Media 1 (1): 9-25.

Lewis, Justin and Sut Jhally. 1998. The Struggle over Media Literacy. Journal of Communication 48 (1): 109-20.

Macedo, Donaldo P. 2006. Literacies of Power: What Americans Are Not Allowed to Know. Boulder, CO.: Westview Press.

Mansell, Robin. 2004. Political Economy, Power and New Media. New Media and Society 6 (1): 7483.

McChesney, Robert W. 2008. The Political Economy of Media: Enduring Issues, Emerging Dilemmas. New York: Monthly Review Press.

McChesney, Robert W. 2013. Digital Disconnect: How Capitalism is Turning the Internet Against Democracy. New York: The New Press.

Miller, Daniel and John Horn. 2014. Lawsuit Challenges a Hollywood Pillar: Unpaid Internships. Los Angeles Times, April 6. Accessed June 24, 2015. http://articles.latimes.com/2014/apr/06/business/la-fi-ct-hollywood-interns-unpaid-internships/3.

Mosco, Vincent. 2011. Communication and Cultural Labour. In The Renewal of Cultural Studies, edited by Paul Smith, 230-37. Philadelphia, PA: Temple University Press.

Olson, Lindsay. 2013. 4 Coping Tips for Surviving a Crummy Internship. US News \& World Report, August 8. Accessed June 24, 2015. http://money.usnews.com/money/blogs/outside-voicescareers/2013/08/08/4-coping-tips-for-surviving-a-crummy-internship.

Ontario Ministry of Labour. 2000. Employment Standards Act. Toronto, Ontario. Accessed June 24, 2015. http://www.e-laws.gov.on.ca/html/statutes/english/elaws statutes 00e41_e.htm.

Perlin, Ross. 2011. Intern Nation: How to Earn Nothing and Learn Little in the Brave New Economy. Brooklyn, NY: Verso Books.

Perlin, Ross. 2013a. Unpaid Interns: Silent No More. The New York Times, July 20. Accessed June 24, 2015. http://www.nytimes.com/2013/07/21/jobs/unpaid-interns-silent-no-more.html.

Perlin, Ross. 2013b. Black Swan Event: The Beginning of the End of Unpaid Internships. Time, July 13. Accessed June 24, 2015. http://business.time.com/2013/06/13/black-swan-event-thebeginning-of-the-end-of-unpaid-internships/.

Potter, W. James. 2004. Theory of Media Literacy: A Cognitive Approach. Thousand Oaks, CA: SAGE Publications.

Potter, W. James. 2014. Media Literacy. Thousand Oaks, CA: Sage.

Saccaro, Matthew. 2014. High-Schoolers' Free Labor: Why the Internship Problem Will Get Even Worse. Salon, May 22. Accessed June 12, 2015.

http://www.salon.com/2014/05/22/high_schoolers_free_labor_why_the_internship_problem_will_ge t even worse/. 
Sagan, Aleksandra. 2013. Unpaid Internships Exploit 'Vulnerable Generation.' CBC News, July 2. Accessed June 12, 2015. http://www.cbc.ca/1.1332839.

Sholle, David, and Stan Denski. 1994. Media education and the (re)production of culture. Westport, CT: Bergin \& Garvey.

Spitznagel, Eric. 2013. Unpaid-Intern Lawsuits Explained. BusinessWeek: Lifestyle, June 27. Accessed June 12, 2015. http://www.businessweek.com/articles/2013-06-27/unpaid-intern-lawsuitsexplained.

Standing, Guy. 2011. The Precariat: The New Dangerous Class. London: Bloomsbury Academic.

United Nations Universal Declaration of Human Rights. 1948, Dec. 10. Accessed June 12, 2015. http://www.un.org/en/documents/udhr/.

United States Department of Labor. 2010. Internship Programs under the Fair Labor Standards Act. Accessed June 12, 2015. http://www.dol.gov/whd/regs/compliance/whdfs71.htm.

\section{About the Author}

Doug Tewksbury

Doug Tewksbury (Ph.D., Penn State, 2010) is Assistant Professor of Communication Studies at Niagara University where he teaches media studies and social justice. His current research explores the way that social movements are using participatory social/mobile technologies, digital labour, and civic engagement to build citizen empowerment. 